\title{
High cell wall-associated proteinase activity of some Streptococcus thermophilus strains (H-strains) correlated with a high acidification rate in milk
}

\author{
S Shahbal, D Hemme *, M Desmazeaud \\ INRA, Station de Recherches Laitières, 78352 Jouy-en-Josas Cedex, France
}

(Received 24 August 1990; accepted 30 January 1991)

\begin{abstract}
Summary - Dairy starter strains Streptococcus thermophilus CNRZ 385 and CNRZ 703 coagulated low heat skim milk in $3 \mathrm{~h}$ while the reference strain CNRZ 302 required more than $10 \mathrm{~h}$. The high acidification rates of these 2 strains ( $\mathrm{H}$-strains) were correlated with the presence of a 10-and 7-fold increase in proteinase activity as compared to 13 other randomly chosen strains (L-strains), including the reference strain CNRZ 302. The level of proteinase activity in M17 broth was similar to the activity of the $\mathrm{Prt}^{+}$Lactococcus lactis ssp lactis strain CNRZ 1076. Proteinase activity of $S$ thermophilus $\mathrm{H}$-strains was found to be cell wall-associated and was not released in the absence of $\mathrm{CaCl}_{2}$ as in the case of $L$ lactis strains. The relevance of these proteinase activities in relation to high acid production rates was confirmed by a proteinase-negative mutant whose growth and proteinase activity were reduced to levels observed for the L-strains.
\end{abstract}

Streptococcus thermophilus / acidification / cell wall-associated proteinase activity / proteinase-negative mutant

Résumé - La forte activité protéinasique de paroi de certaines souches de Streptocccus thermophilus (souches $\mathrm{H}$ ) explique leur forte vitesse d'acidification du lait. Les souches de bactéries lactiques Streptococcus thermophilus CNRZ 385 et CNRZ 703 coagulaient le lait écrémé "low heat" en $3 \mathrm{~h}$ alors que la souche de référence CNRZ 302 demandait $10 \mathrm{~h}$. La forte vitesse d'acidification de ces souches $(H)$ était corrélée avec une activité protéinasique respectivement 10 et 7 fois plus forte que celle de 13 autres souches (L) prises au hasard dont la souche de référence CNRZ 302. Ces hautes activités protéinasiques en milieu M17 étaient du même ordre de grandeur que celle de la souche Prt+ Lactococcus lactis ssp lactis CNRZ 1076. L'activité protéinasique des souches $\mathrm{H}$ était liée à la paroi et n'était pas libérée en absence de $\mathrm{CaCl}_{2}$. La relation entre la haute activité protéinasique et la forte acidification a été confirmée par l'obtention, à partir de la souche CNRZ 385, d'un mutant Prt dont la croissance et l'activité protéinasique étaient réduites au niveau de celles de la souche L CNRZ 302.

Streptococcus thermophilus / acidification / activité protéinasique de parol / mutant protélnase-négatif

\footnotetext{
* Correspondence and reprints
} 


\section{INTRODUCTION}

Growth of lactic acid bacteria in milk depends on their ability to metabolize nonlimiting concentrations of lactose $(45-50 \mathrm{~g} /$ 1), and to hydrolyze caseins which represent $\approx 80 \%$ of milk proteins and are considered to be the main nitrogen source. In milk, the concentration of free amino acids and low molecular weight peptides is very low and allows growth to a cell density corresponding to $8-16 \%$ of the maximum found when caseins are utilized. These levels are well below the minimum necessary to support rapid acid production (Thomas and Pritchard, 1987). Consequently, for further growth, the starter bacteria have to utilize caseins which are hydrolyzed to peptides and amino acids by extracellular proteinases and peptidases.

Streptococcus thermophilus is a thermophilic lactic acid bacterium used in the production of many fermented milk foods (Accolas et al, 1980). Usually, $S$ thermophilus strains are unable to decrease the $\mathrm{pH}$ lower than 5.2, and for this reason they are commonly mixed with other starter strains such as lactobacilli.

Earlier reports indicate that $S$ thermophilus CNRZ 385 is a higher acidifying strain in milk than strain CNRZ 302 (ACcolas et al, 1977; Bouillane and Desmazeaud, 1980). Aldolase activity was also 10-fold higher in strain CNRZ 385 than in strain CNRZ 302 (Hemme et al, 1980). Moreover, Lactobacillus extracts did not stimulate growth of strain CNRZ 385, as was observed for strain CNRZ 302 (Hemme et al, 1981a). These findings suggested that strain CNRZ 385 could maintain a neutral internal $\mathrm{pH}$ for a longer time than strain CNRZ 302, thus enabling it to grow at low external pH values (Hemme et al, 1980, 1981b).

The aim of this study was to better understand the basis of enhanced acidifying ability of high acidifying organisms such as $S$ thermophilus CNRZ 385.

\section{MATERIALS AND METHODS}

\section{Strains and culture media}

All Streptococcus thermophilus strains used in this study (98 strains) were obtained from the CNRZ collection at Jouy-en-Josas, France. Strain CNRZ 385, isolated from a Japanese yoghourt in 1971 and strain CNRZ 703, isolated from a Mongolian yoghourt in 1974, are "fast acidifying strains" (see Accolas et al, 1977). Strain CNRZ 302 isolated from Gruyère cheese in 1964 was a "standard" strain representative of the average acidifying ability in milk of most strains of $S$ thermophilus. Lactococcus lactis ssp lactis proteinase-positive ( $\mathrm{Prt}^{+}$) strain CNRZ 1076 and the corresponding proteinasenegative (Prt) variant $L$ lactis ssp lactis CNRZ 1075 were utilized as $L$ lactis references.

Two culture media were used: low heat skim milk powder (NIZO, The Netherlands), reconstituted $(10 \% \mathrm{~W} / \mathrm{v})$ with sterile water, and M17 medium with $10 \mathrm{~g}$ lactose/ (Terzaghi and Sandine; $1975)$. Inocula $(2 \%)$ from precultured strains in the same medium were used for experimental cultures at $42^{\circ} \mathrm{C}$.

\section{Production of the mutant strain}

Mutants from strain CNRZ 385 were obtained by

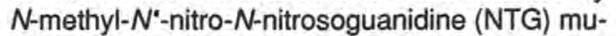
tagenesis, as described by Renault and Heslot (1987). Selection of proteinase-negative mutants was carried out by plating mutagenized cells on fast slow differential agar (FSDA), which is an efficient means of differentiating the $\mathrm{Prt}^{+}$ $L$ lactis strains and their Prt variants according to colony size (Huggins and Sandine, 1984). Mutants with a Prt phenotype were then tested for growth in M17 broth, carbohydrate utilization on API $50 \mathrm{CH}$ and for different enzymatic activities on API ZYM (API, la Balme-les-Grottes, France). One mutant (CNRZ 1357), that was similar to the parental strain except for growth on FSDA medium and in milk, was chosen for this study. 


\section{Assay of proteinase activity}

Cultures grown in M17 medium were harvested at the end of the exponential growth phase. Cells were centrifuged at $12000 \mathrm{~g}$ for $10 \mathrm{~min}$ at $4{ }^{\circ} \mathrm{C}$, washed twice in $50 \mathrm{mmol}^{-1}$ Trishydrochloride $(\mathrm{pH} \mathrm{7.0)}$ and resuspended at a concentration of $0.1 \mathrm{~g}$ of cells (wet weight) per $\mathrm{ml}$ of buffer. To prepare cell wall fractions, $S$ thermophilus cells from $500-\mathrm{ml}$ batch cultures were harvested at the end of the exponential growth phase. The pellets were suspended in $\mathrm{Na}$-phosphate buffer $50 \mathrm{mmol}^{-1}(\mathrm{pH} \mathrm{7.0)}$ and stored at $-30^{\circ} \mathrm{C}$ overnight. After cells had been disrupted 10 times (10 tons pressure) by an Xpress apparatus (Nike 43 HD 30 T, Sweden), the suspension of disintegrated cells was thawed, supplemented with DNAse and RNAse (both $10 \mu \mathrm{g} / \mathrm{ml}$ ) and incubated for $30 \mathrm{~min}$ at room temperature. Cell fractions were separated by centrifugation: whole cells were eliminated at $500 \mathrm{~g}$ for $15 \mathrm{~min}$ and cell wall/membrane fractions were obtained at $12000 \mathrm{~g}$. After a 30-min incubation with Triton $X-100,(0.05 \%$ final conc), cell membranes remained in the $8000 \mathrm{~g}$ supernatant.

Proteinase activity was assayed as described by Monnet et al (1987) using $0.1 \%{ }^{14} \mathrm{C}$ methylate whole casein (specific activity 7.3 $\mathrm{MBq} / \mathrm{g}$ ) prepared as described by Donnelly et al (1980). To $100 \mu \mathrm{l}$ of casein was added $100 \mu \mathrm{l}$ of cells (10 mg wet weight) or cell wall fractions (400 $\mathrm{ng}$ of protein). One unit of activity is defined as the percentage of ${ }^{14} \mathrm{C}$-methylated whole casein hydrolyzed after $10 \mathrm{~min}$.

\section{RESULTS}

\section{High acidification of low heat skim milk by strains CNRZ 385 and CNRZ 703}

$S$ thermophilus strains CNRZ 385, CNRZ 703, CNRZ 302 and the Prt mutant CNRZ 1357 were compared for their ability to acidify low heat skim milk during growth by using the $\mathrm{pH}$ meter. High acidifying strains CNRZ 385 and CNRZ 703 required only $3 \mathrm{~h}$ of incubation to decrease the $\mathrm{pH}$ to 5.0 (condition where coagulation began), while more than $10 \mathrm{~h}$ were required for both normal acidifying strain CNRZ 302 and mutant CNRZ 1357 (fig 1).

The high acidification rate of milk correlated with increased production of $L(+)$ lactate and galactose which accumulated in the medium (results not shown).

No marked difference in growth or acidification occurred between strains CNRZ 385 and CNRZ 703 strain CNRZ 302 and the CNRZ 1357 mutant when grown in M17 broth (fig 2).

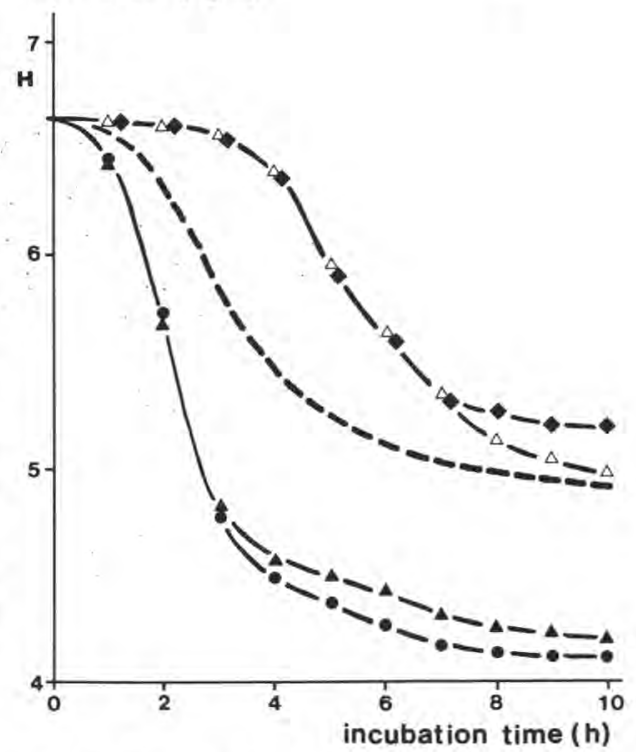

Fig 1. Acidification of low heat skim milk by $S$ thermophilus H-strains CNRZ 385 (A) and CNRZ 703 (0), L-strain CNRZ $302(\Delta)$ and the low proteinase activity mutant CNRZ 1357 (\$). Inoculum $2 \%$, culture at $42{ }^{\circ} \mathrm{C}$. For comparison, the dashed line indicates acidification of autoclaved skim milk by CNRZ 302.

Acidification du lait écrémé "low heat» par les souches H CNRZ 385 (ㅅ) et CNRZ 703 (). la souche L CNRZ 302 ( ) et le mutant à faible activité protéinasique CNRZ $1357(\Delta)$ de S thermophilus. Inoculum $2 \%$, culture à $42{ }^{\circ} \mathrm{C}$. Pour comparaison, la ligne en pointillés indique la croissance de CNRZ 302 dans le lait écrémé autoclavé. 


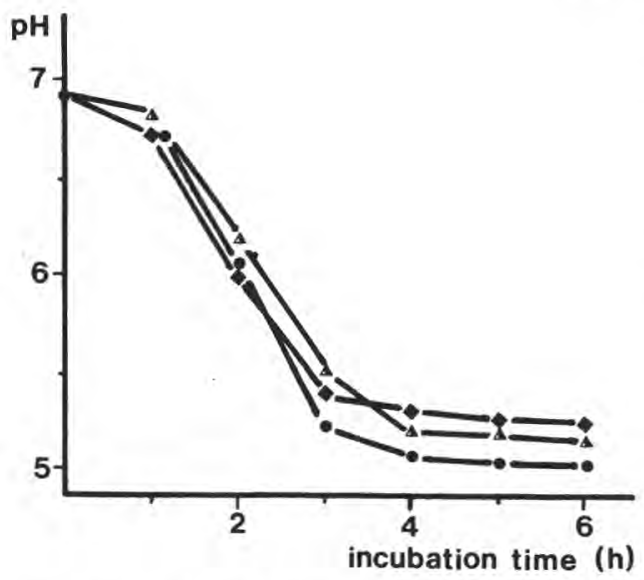

Fig 2. Acidification of $M 17$ broth by $S$ thermophilus $\mathrm{H}$-strains CNRZ $385(\mathbf{\Delta})$ and CNRZ $703(\bullet)$, L-strain CNRZ 302 ( ), and the low proteinase activity mutant CNRZ $1357(\Delta)$. Inoculum $2 \%$, culture at $42{ }^{\circ} \mathrm{C}$.

Acidification du milieu M17 par les souches $H$ CNRZ 385 (4) et CNRZ 703 (•), la souche L CNRZ 302 ( ) et le mutant à faible activité protéinasique CNRZ 1357 ( $\Delta$ ) de S thermophilus. Inoculum $2 \%$, culture à $42^{\circ} \mathrm{C}$.

\section{Proteinase activity of whole cells and cell fractions}

Proteinase activity of whole cells of CNRZ 385, CNRZ 703, CNRZ 302 and CNRZ 1357 mutant was measured with ${ }^{14} \mathrm{C}$ methylated whole casein. Enzyme activities for strains CNRZ 385 and CNRZ 703 were 10- and 7-fold higher, respectively, as compared to the reference strain CNRZ 302 and the mutant strain CNRZ 1357 (table I).

Strains possessing high proteinase activity, ie strains CNRZ 385 and CNRZ 703, are defined as $\mathrm{H}$-strains, whereas other strains with low activity are called Lstrains. Proteinase activity of the $\mathrm{H}$-strains was equivalent to that of $\mathrm{Prt}^{+} L$ lactis strain CNRZ 1076. The L-strains and Prt mutant
CNRZ 1357 exhibited low proteinase activity equivalent to that of the Prt variant $L$ lactis CNRZ 1075.

Using the procedure described by Mills and Thomas (1978) which is successful for lactococci including $L$ lactis spp lactis

Table I. Whole cell proteinase activity of 15 strains of $S$ thermophilus and the mutant CNRZ 1357 , and 2 strains of $L$ lactis spp lactis. Proteinase activity was measured at $37^{\circ} \mathrm{C}$ with ${ }^{14} \mathrm{C}$ methylated whole casein (one unit represents $1 \%$ of casein hydrolyzed in $10 \mathrm{~min}$; see Materials and Methods for details).

Activité protéinasique des cellules entières de 15 souches sauvages et du mutant CNRZ 1357 de Streptococcus thermophilus et de 2 souches de Lactococcus lactis ssp lactis. L'activité protéinasique était mesurée à $37^{\circ} \mathrm{C}$ sur la caséine ${ }^{14} \mathrm{C}$-méthylée (Une unité correspond à l'hydrolyse de $1 \%$ de caséine en $10 \mathrm{~min}$, voir Matériel et méthodes pour le détail).

\section{CNRZ strains Unit of proteinase activity}

$\begin{array}{cc}\begin{array}{c}\text { S thermophilus } \\ \text { H-strains : }\end{array} \\ 385 \\ 703 & 2.40 \\ \text { L-strains : } & 1.56 \\ 160 & \\ 1237 & 0.37 \\ 1201 & 0.36 \\ 302 & 0.34 \\ 21 & 0.33 \\ 307,1157,1205 & 0.27 \\ 1203 & 0.20 \\ 1206,1213 & 0.19 \\ 1198 & 0.16 \\ 1208 & 0.12 \\ \text { Prt mutant 1357 } & 0.08 \\ \text { L lactis } & 0.19 \\ \text { Prt } 1076 & \\ \text { Prt 1 } 075 & 2.21 \\ & \end{array}$

$\mathrm{H}$ - and L-strains: high and low proteinase activity strains; Prt": protease positive strain; Prt: protease negative strain.

Souches $H$ et $L$ : souches à forte et faible activité protéinique; $\mathrm{Prt}^{+}$: souche protéolytique; $\mathrm{Prt}$ : souche non protéolytique. 
NCDO 763 (Monnet et al, 1987), no significant extracellular proteinase activity was observed in the absence of $\mathrm{CaCl}_{2}$.

Proteinase activity in cell wall fractions of strains CNRZ 385, CNRZ 703, CNRZ 302 and the CNRZ 1357 mutant were determined with ${ }^{14} \mathrm{C}$-methylated whole casein. As for whole cell activity, 10 and 7 . fold higher activities were found in cell wall fraction from strains CNRZ 385 and CNRZ 703 respectively, as compared to the $\mathrm{L}$ strain CNRZ 302 and the CNRZ 1357 mutant (results not shown).

\section{Distribution of proteinase activity in $\mathrm{S}$ thermophilus strains}

Since the fast slow differential agar (FSDA) was an efficient medium for differentiating $\mathrm{H}$-strains which gave large colonies from L-strains which gave small colonies (fig 3), 95 other strains of $S$ thermophilus were tested on this medium to study the distribution of proteinase activity in this species. None of these strains displayed the typical characteristics of $\mathrm{H}$-strain colonies. Moreover none of these 13 strains, randomly chosen from the aforementioned 95 strains, showed marked proteinase activity using the ${ }^{14} \mathrm{C}$ methylated whole casein assay (table I).

\section{DISCUSSION}

These results represent the first report that high proteinase activity is associated with the cell wall of some $S$ thermophilus strains. High proteinase activity of strains CNRZ 385 and CNRZ 703 (H-strains) correlated with a high acidification rate for low heat skim milk compared to the normal acidifying strain CNRZ 302 and the Prt mutant CNRZ 1357 (L-strains). No differ- ences in growth and acidification were observed between $\mathrm{H}$ - and L-strains in $\mathrm{M} 17$ broth. Similar findings were also reported for $L$ lactis ssp lactis $\mathrm{C} 2$ by Citti et al (1965). The fact that $\mathrm{H}$-strains acidify low heat skim milk but not M17 medium more rapidly than L-strains could be directly related to the presence of sufficient concentrations of utilizable nitrogen in M17 medium.

Results from this study also confirm previous findings in that most strains of $S$ thermophilus including CNRZ 302 were stimulated by addition of Lactobacillus extracts containing protease, but not strain CNRZ 385 (Hemme et al, 1981a). High proteinase activity of the $\mathrm{H}$-strains allowed these strains to utilize entire milk proteins as a nitrogen source more efficiently than the Lstrains. In addition, $\mathrm{H}$ - and $\mathrm{L}$-strains were

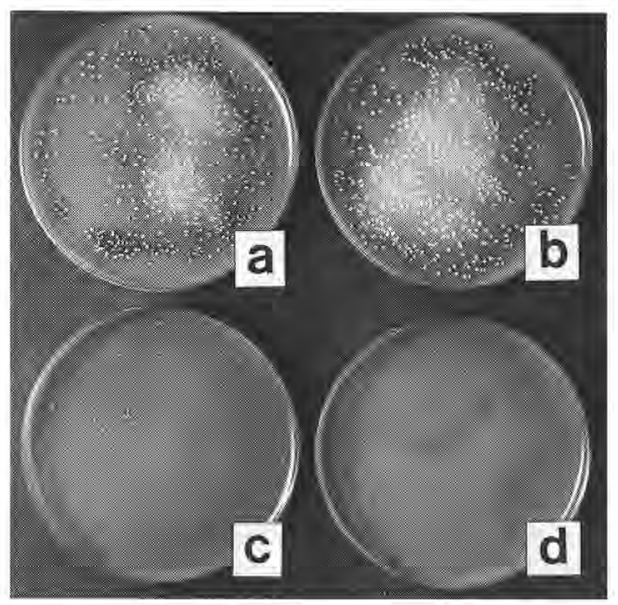

Fig 3. Colonies of $S$ thermophilus on fast slow differential agar (FSDA) after $48 \mathrm{~h}$ of incubation at $37^{\circ} \mathrm{C}$. (a) $\mathrm{H}$-strain CNRZ 385; (b) $\mathrm{H}$-strain CNRZ 703; (c) L-strain CNRZ 302; (d) proteinase-negative mutant CNRZ 1357.

Aspect des colonies de $\mathrm{S}$ thermophilus sur le milieu FSDA après $48 \mathrm{~h}$ d'incubation à $37^{\circ} \mathrm{C}$. (a) souche H CNRZ 385; (b) souche H CNRZ 703; (c) souche L CNRZ 302; (d) mutant protéinase négatif CNRZ 1357. 
more easily differentiated by their growth in low heat milk (fig 1) than in autoclaved milk which presents partial degradation of casein (Tyler and Weiser, 1942; Foster, 1952; Auclair 1964; Lorient et al, 1977).

Studies involving the mutant CNRZ 1357 showed that the loss of fast acidifying ability in milk was correlated to the loss of high proteinase activity. Localization of proteinase activity in the cell wall was important for rapid growth of $S$ thermophilus $\mathrm{H}$-strains in milk. The L-strains grew better in low heat milk than Prt variants of $L$ lactis (results not shown). A possible explanation is that the L-strains, when grown in milk, possess higher proteinase activity than the Prt $L$ lactis. For this reason, these strains probably should be called Lstrains rather than Prt strains.

To confirm that both $\mathrm{H}$-strains CNRZ 385 and CNRZ 703 were correctly identified as $S$ thermophilus species, DNA hybridization was performed between DNA from the specific $S$ thermophilus probe pNST21 (Colmin et al, 1990) and DNA of strains CNRZ 385 and CNRZ 703 as well as the $S$ thermophilus type strain (ATCC 19258 or NCDO 573). The specific $S$ thermophilus probe strongly hybridized with the 4 strains tested, while no signal was observed against DNA from all other genera examined (Fayard, Colmin and Accolas unpublished results).

The advantage of introducing an analogous protease system in other strains of $S$ thermophilus can be foreseen. It could also be interesting to manufacture fermented milk with pure $\mathrm{H}$-strains of $S$ thermophilus, without the use of heat-treated or supplemented milk, as is commonly done (Marshall et al, 1982).

A third $\mathrm{H}$-strain (CNRZ 1447), isolated by Nestec SA, Switzerland, from an Indian fermented milk (Dahi), has been found since acceptation of the paper.

\section{ACKNOWLEDGMENTS}

We are indebted to JP Accolas for providing information on physiological aspects of $S$ thermophilus, P Renault for obtaining the mutants and $\checkmark$ Monnet for advice in proteinase activity measurement. We are grateful to D Winters for help in preparing the English version of this paper.

\section{REFERENCES}

Accolas JP, Bloquel R, Didienne R, Regnier J (1977) Propriétés acidifiantes des bactéries lactiques thermophiles en relation avec la fabrication du yoghourt. Lait 57, 1-23

Accolas JP, Hemme D, Desmazeaud M, Vassal L, Bouillanne C, Veaux M (1980) Les levains lactiques thermophiles : propriétés et comportement en technologie laitière. Une revue. Lait 60, 487-524

Auclair J (1964) Les substances antibactériennes du lait cru et leur rôle en technologie laitière. 4th Int Symp Food Microbiol, SIK, Göteborg (Sweden) 281-296

Bouillanne C, Desmazeaud M (1980) Étude de quelques caractères de souches de Streptococcus thermophilus utilisées en fabrication de yoghourt et proposition d'une méthode de classement. Lait 60, 458-473

Citti JE, Sandine WE, Elliker PR (1965) Comparison of slow and fast acid-producing Streptococcus lactis. J Dairy Sci 48, 14-18

Colmin C, Pebay M, Simonet JM, Decaris B (1990) Detection of restriction polymorphism in Streptococcus salivarius ssp thermophilus by hybridization with a species-specific DNA probe. FEMS Microbiol Rev 87, P32; Communication, 3rd Symp Lactic Acid Bacteria, Wageningen, The Netherlands

Donnelly WJ, Barry G, Richardson T (1980) ${ }^{14} \mathrm{C}$ methylated $\beta$-casein as a substrate for plasmin, and its application to the study for milk transformation. Biochim Biophys Acta 626, 117-126

Foster EM (1952) The effect of heat on milk as a culture medium for lactic acid bacteria. $J$ Dairy Sci 35, 988-997 
Hemme D, Wahl D, Nardi M (1980) Variations de l'équipement enzymatique de Streptococcus thermophilus. Lait 60, 111-129

Hemme D, Schmal V, Auclair J (1981a) Effect of the addition of extracts of thermophilic lactobacilli on acid production by Streptococcus thermophilus in milk. J Dairy Res 48, 139148

Hemme D, Nardi M, Wahl D (1981b) Propriétés des lacticodéshydrogénases de Streptococcus thermophilus indépendantes du fructose 1,6-diphosphate. Lait 61, 1-18

Huggins AR, Sandine WE (1984) Differentiation of fast and slow milk-coagulating isolates in strains of lactic streptococci. J Dairy Sci 67, 1674-1679

Lorient D, Bracquart P, Alais C (1977) Dégradation thermique des caséines $\alpha$ s et $\beta$ de vache. IV. Substances peptidiques libérées. Propriétés activatrices de la croissance des bactéries lactiques. Ann Biol Anim Biochim Biophys 17, 215-235

Marshall VM, Cole WM, Mabbitt LA (1982) Yoghurt made from single starter organisms using heat- or enzyme-treated milk or milk to which casein hydrolysate of sodium formate is added. J Dairy Res 49, 147-152

Mills OE, Thomas TD (1978) Release of cell wall-associated proteinase(s) from lactic streptococci. NZ J Dairy Sci Technol 13, 209215

Monnet V, Le Bars D, Gripon JC (1987) Purification and characterization of cell wall proteinase from Streptococcus lactis NCDO 763. $J$ Dairy Res 54, 247-255

Renault P, Heslot H (1987) Selection of Streptococcus lactis mutants defective in malolactic fermentation. Appl Environ Microbiol 53, 320324

Terzaghi BE, Sandine WE (1975) Improved medium for lactic streptococci and their bacteriophages. Appl Microbiol 29, 807-813

Thomas TD, Pritchard GG (1987) Proteolytic enzyme of dairy starter cultures. FEMS Microbiol Rev 46, 245-268

Tyler ME, Weiser HH (1942) Factors affecting Swiss cheese starter activity. Effect of heattreatment and source of milk. J Dairy Sci 25, 939-948 